\title{
Pengaruh Kepemimpinan Transformasional dan Pelatihan Terhadap Profesionalisme Prajurit melalui Motivasi Variabel Intervening di Jajaran Satuan Lintas Laut Militer Jakarta
}

\author{
Jan Lucky Boy Siburian
}

Universitas Negeri Jakarta,Jakarta, Indonesia, 13220

*Email: janluckyboysiburian@gmail.com

Doi : https://doi.org/10.37339/jurnal e-bis.v4i2.252

Diterbitkan oleh Politeknik Dharma Patria Kebumen

\section{Info Artikel}

Diterima :

23-07-2020

Diperbaiki :

23-07-2020

Disetujui :

13-11-2020

\begin{abstract}
ABSTRAK
Penelitian ini membahas peran motivasi sebagai variabel intervening dari pengaruh kepemimpinan transformasional dan pelatihan terhadap profesionalisme prajurit di jajaran Satuan Lintas Laut Militer. Penelitian menggunakan penelitian kuantitatif dengan data primer. Peneliti menggunakan Structural Equation Modelling dalam melakukan analisis data yang telah didapat dari Satlinlamil TNI AL. Berdasarkan kriteria yang telah ditentukan, peneliti mendapatkan 220 data responden yang dianalisis dengan menggunakan software AMOS. Berdasarkan data output AMOS, dapat terlihat bahwa pelatihan, kepemimpinan transformasional, dan motivasi mempengaruhi profesionalisme prajurit, kemudian motivasi dapat berperan sebagai variabel mediasi.

Kata Kunci: kepemimpinan transformasional, pelatihan, motivasi, profesionalisme

ABSTRACT

This study discusses the role of motivation as an intervening variable of the influence of transformational leadership and training on the professionalism of soldiers in the ranks of the Military Cross Sea Unit. This research uses quantitative research with primary data. Researchers used Structural Equation Modeling in analyzing the data obtained from the TNI AL Satlinlamil. Based on predetermined criteria, the researcher obtained 220 respondent data which were analyzed using AMOS software. Based on the AMOS output data, it can be seen that training, transformational leadership, and motivation affect the professionalism of soldiers, then motivation can act as a mediating variable.
\end{abstract}

Keywords: transformational leadership, training, motivation, professionalism 


\section{PENDAHULUAN}

Dalam menjaga kemerdekaan dan keamanan bangsa, peran TNI sebagai tentara profesional sangat penting. Menyadari pentingnya peran TNI, pemerintah telah melaksanakan banyak kegiatan untuk memberdayakan TNI agar memiliki kemampuan, profesionalisme dan kinerja yang optimal dalam mencapai tujuan nasional. Di sisi lain, keluhan sering terdengar dari orang-orang yang terkait dengan aparatur TNI yang tidak profesional karena pelanggaran yang dilakukan oleh oknum TNI. Aparat yang terkadang kurang bersahabat, serta profesionalisme yang dilanggar saat bertugas oleh beberapa prajurit. Profesionalisme TNI juga dinilai kurang maksimal bahkan ada kecenderungan menurun. Penurunan profesionalisme tersebut tersampaikan oleh fakta di lapangan terkait praktek dwifungsi TNI. Misalnya saja kegiatan pembuatan MoU oleh TNI dengan organisasi pemerintahan. Selama delapan tahun ke belakang, terjadi penandatanganan $40 \mathrm{MoU}$ oleh TNI dengan organisasi pemerintahan. Pasalnya kegiatan yang dilakukan di luar profesionalitas TNI seperti penyuluhan KB hingga persawahan dan pembangunan infrastruktur. Kemudian adanya Peraturan Presiden (perpres) Nomor 37 Tahun 2019 tentang Jabatan Fungsional TNI juga semakin menguatkan Dwifungsi TNI. Jika dilihat dari UU No.34/2004 menyatakan bahwa Tentara Nasional Indonesia dibangun dan dikembangkan secara professional. Jika mendapat jabatan fungsional dikhawatirkan profesionalisme dapat berkurang. Jatidiri TNI adalah Tentara Profesional, hal tersebut tertuang dalam Pasal 2 UU TNI No. 34 Tahun 2004 tentang TNI.

Data yang menyangkut dengan profesionalisme prajurit KRI di jajaran Satlinlamil yang kurang kondusif sehingga menimbulkan pelanggaran yang masuk dalam proses hukum:

Tabel 1. Data Pelanggaran

\begin{tabular}{|c|l|c|c|c|c|}
\hline NO & \multicolumn{1}{|c|}{$\begin{array}{c}\text { JENIS } \\
\text { PERKARA }\end{array}$} & \multicolumn{3}{c|}{ TAHUN } & TOTAL \\
\hline & \multicolumn{1}{|c|}{2015} & 2016 & 2017 & \\
\hline 1. & Desersi & 1 & 2 & 2 & 5 \\
\hline 2. & Lalai melaks tugas & 3 & 4 & 4 & 11 \\
\hline 3. & Narkotika & 1 & - & 1 & 2 \\
\hline 4. & Asusila & - & 1 & 1 & 2 \\
\hline 5. & Penganiyaan & - & 1 & - & 1 \\
\hline 6. & Penadahan & - & - & 2 & 2 \\
\hline 7. & Calo & - & 1 & - & 1 \\
\hline 8. & Pencurian dan Kekerasan & - & - & 5 & 5 \\
\hline & Total & 5 & 9 & 15 & 29 \\
\hline
\end{tabular}

Sumber : Diskum Satlinlamil 2015, 2016, 2017

Berdasarkan data dinas hukum TNI AL (2018) beberapa kali terjadi pelanggaran terkait profesionalisme prajurit di jajaran Satlinlamil. Pelanggaran profesi mulai dari kasus desersi, kelalaian, hingga narkotika dan kekerasan naik setiap tahunnya dari tahun 2015 hingga 2017. Pelatihan yang direncanakan oleh Satlinlamil terhadap prajurit yang terkait tugas pokoknya belum sepenuhnya di laksanakan dengan baik dan benar, dimana pelatihan belum menitikberatkan kepada tugas tanggungjawabnya sesuai bidang dan kemampuannya sehingga tingkat profesionalisme berkurang sebagai pengawak Alutsita.

Pemberian motivasi kepada prajurit diberikan dalam bentuk pemenuhan kebutuhan hidup prajurit. Pemenuhan kebutuhan dapat ditafsirkan dengan pemenuhan kompensasi finansial langsung yang terdiri dari pembayaran yang diterima oleh prajurit dalam bentuk gaji pokok, tunjangan yang sesuai dengan kebutuhan hidup sehingga prajurit dapat memenuhi kebutuhan baik papan, sandang dan pangan. Disamping itu, pemberian kompensasi finansial tidak langsung seperti asuransi, jaminan sosial dan sejenisnya. Kemudian kompensasi non financial terkait 
pemberian cuti dan hari libur. Tidak kalah pentingnya juga dalam meningkatkan profesionalisme seorang prajurit seperti halnya dorongan semangat bekerja, dimana dalam suatu manajemen yang sudah di programkan/direncanakan dapat memberikan penghargaan dalam melaksanakan tugas dengan demikian prajurit merasa termotivasi untuk berbuat lebih baik dan dapat dihandalkan. Pelatihan prajurit di jajaran Satlinlamil Jakarta yang dilaksanakan tersebut diharapkan akan dapat berpengaruh terhadap profesionalisme prajurit. Pada kenyataannya motivasi prajurit yang berdinas utamanya di KRI di jajaran Satuan Lintas Laut Militer Jakarta (Satlinlamil Jakarta) sedikit menurun, ini dikarenakan beban kerja yang cukup tinggi dan sebagian haknya kadang kala sedikit terabaikan dikarena harus menjalankan tugas setiap saat dan setiap waktu.

Dengan judul peran Motivasi sebagai variabel mediasi dari Pengaruh Kepemimpinan Tansformasional dan Pelatihan Terhadap Profesionalisme Prajurit di Jajaran Satuan Lintas Laut Militer Jakarta, rumusan masalah yang diteliti difokuskan kepada:

a) Apakah kepemimpinan transformasional mempengaruhi motivasi di jajaran Satuan Lintas Laut Militer Jakarta?

b) Apakah pelatihan mempengaruhi motivasi di jajaran Satuan Lintas Laut Militer Jakarta ?

c) Apakah kepemimpinan transformasional mempengaruhi profesionalisme Prajurit di jajaran Satuan Lintas Laut Militer Jakarta?

d) Apakah pelatihan mempengaruhi profesionalisme Prajurit di jajaran Satuan Lintas Laut Militer Jakarta?

e) Apakah motivasi mempengaruhi profesionalisme Prajurit di jajaran Satuan Lintas Laut Militer Jakarta?

f) Apakah motivasi berperan menjadi variabel intervening dalam pengaruh kepemimpinan transformasional terhadap profesionalisme prajurit di jajaran Satuan Lintas Laut Militer Jakarta?

g) Apakah motivasi berperan menjadi variabel intervening dalam pengaruh pelatihan terhadap profesionalisme prajurit di jajaran Satuan Lintas Laut Militer Jakarta?

Tujuan secara akademis, penulis berharap dapat meningkatkan pengetahuan, memperluas wawasan serta memperkaya khasanah perpustakaan bidang pertahanan, khususnya tentang profesionalitas prajurit pengawak Satuan Lintas Laut Militer Jakarta. Penulis berikutnya dapat melakukan pendekatan, metode dan fokus yang berbeda. Tujuan secara praktis, membantu Prajurit di jajaran Satuan Lintas Laut Militer Jakarta mengetahui tentang kepemimpinan transformasional, pelatihan, motivasi dan profesionalisme prajurit yang berguna dalam menjalankan tugas pokok sebagai diberikan oleh pemimpin. Serta sebagai referensi bagi Komandan dan pejabat terkait dalam menerapkan kepemimpinan transformasional, pemberian pelatihan dan motivasi untuk meningkatkan profesionalisme prajurit dalam menjalankan tugas pokoknya.

\section{METODE}

Profesionalisme perilaku, tujuan, atau kualitas yang menjadi ciri atau menandai suatu profesi atau orang yang profesional. Profesionalisme merupakan cerminan perilaku manusia dalam profesinya. Berdasarkan para ahli secara etimologi profesi dari kata profesion yang berarti pekerjaan. Profesional artinya orang yang ahli. Bagi sebagian orang, menjadi profesional dapat berarti berpakaian dengan cerdas di tempat kerja, atau melakukan pekerjaan dengan baik. Bagi yang lain, menjadi profesional berarti memiliki gelar lanjutan atau sertifikasi lainnya yang dibingkai dan digantung di dinding kantor. Profesionalisme mencakup semua definisi dalam pekerjaan (Rulandri, 2017). Indikator profesionalisme adalah kreativitas, inovasi, kompetensi, responsifitas dan integritas. 
Kepemimpinan merupakan peran sentral dalam suatu organisasi. Menurut Bolden (2014), Kepemimpinan adalah fenomena kompleks yang menyentuh begitu banyak proses penting lain seperti proses organisasional, sosial, dan personal. Kepemimpinan sangat bergantung pada sebuah proses memengaruhi, di mana orang terinspirasi untuk bekerja mencapai tujuan kelompok tidak melalui paksaan, tapi melalui motivasi personal. Robbins dan Coulter (2014) menyatakan bahwa, kepemimpinan adalah apa yang pemimpin lakukan, proses memimpin kelompok serta mempengaruhinya untuk mencapai tujuan. Rosing dan Zacher (2017) mendefinisikan bahwa kepemimpinan transformasional sebagai pemimpin yang mempunyai kekuatan untuk mempengaruhi bawahan dengan cara-cara tertentu. Dengan penerapan kepemimpinan transformasional bawahan akan merasa dipercaya, dihargai, loyal dan respek kepada pimpinannya. Indikator pemimpin dengan tipe kepemimpinan transformasional diantaranya berkharisma, menginspirasi, cerdas serta memperhatikan bawahan.

Pelatihan menghadirkan peluang utama untuk memperluas basis pengetahuan semua prajurit, umumnya masyarakat menganggap pengembangan SDM terlampau mahal. Prajurit yang menghadiri sesi pelatihan juga kehilangan waktu kerja yang dapat menunda penyelesaian tugas utamanya. Namun terlepas dari potensi kelemahan tersebut, pelatihan dan pengembangan memberikan manfaat baik secara individu maupun organisasi yang menjadikan biaya dan waktu yang dikorbankan sebagai investasi yang berharga. Pengembalian investasi dari pelatihan dan pengembangan SDM akan terlihat di masa yang akan datang (Noe, et. al., 2003). Prinsip-prinsip Pelatihan adalah suatu perbaikan kinerja dan meningkatkan motivasi kerja para karyawan yang dibebankan padanya, sehingga karyawan mengalami kemajuan dalam hal pengetahuan, keterampilan dan keahliannya sesuai dengan bidang pekerjaannya. indikator yang digunakan diantaranya peranan Instruktur dan peserta, isi pelatihan, cara melatih, serta sasaran yang diinginkan.

Motivasi merupakan suatu keadaan atau kondisi yang mendorong, merangsang atau menggerakan seseorang dan juga faktor penentu kinerja seseorang untuk melakukan sesuatu atau kegiatan yang dilakukannya untuk mencapai tujuannya. Motivasi sangatlah penting untuk diterapkan demi menentukan suatu keputusan yang akan diambil dalam suatu pekerjaan dan dalam pelaksanaan tugas. Penelitian ini akan menggunakan indikator Daya Pendorong/Kemauan, Kerelaan, Membentuk Keterampilan, Tanggung Jawab dan Tujuan.

Berdasarkan Rowland (2016) dalam penelitiannya yang berjudul The Validation of a Comprehensive Model of Professionalism menyatakan bahwa model profesionalisme yang dikembangkan merupakan model komprehensif yang menangani masalah profesionalisme dengan menggunakan sebelas indikator sebagai landasannya. Pada dasarnnya terdapat beberapa hal yang menjadi landasan professional diantaranya pelatihan dan motivasi karyawan.

Selanjutnya, penelitian Nathan (2012) tentang The Perceptions of Professionalism in Athlethic menjelaskan bahwa profesionalisme adalah kombinasi dari kompetensi, pemahaman hukum/etika, pengetahuan dan kualitas kemanusiaan. Berbagai disiplin ilmu menunjukkan profesionalisme sangat dibutuhkan dalam setiap profesi. Profesionalisme dipengaruhi oleh motivasi dan pelatihan dalam atletik. Penelitian Rakib (2016) memiliki hasil bahwa pelatihan berpengaruh terhadap profesionalisme.

Sementara itu, Rahmawati (2012) dengan penelitiannya menemukan bahwa motivasi berpengaruh terhadap profesionalisme. Kerangka pemikiran variabel kepemimpinan transformasional, pelatihan, motivasi dan profesionalisme sebagai berikut: 


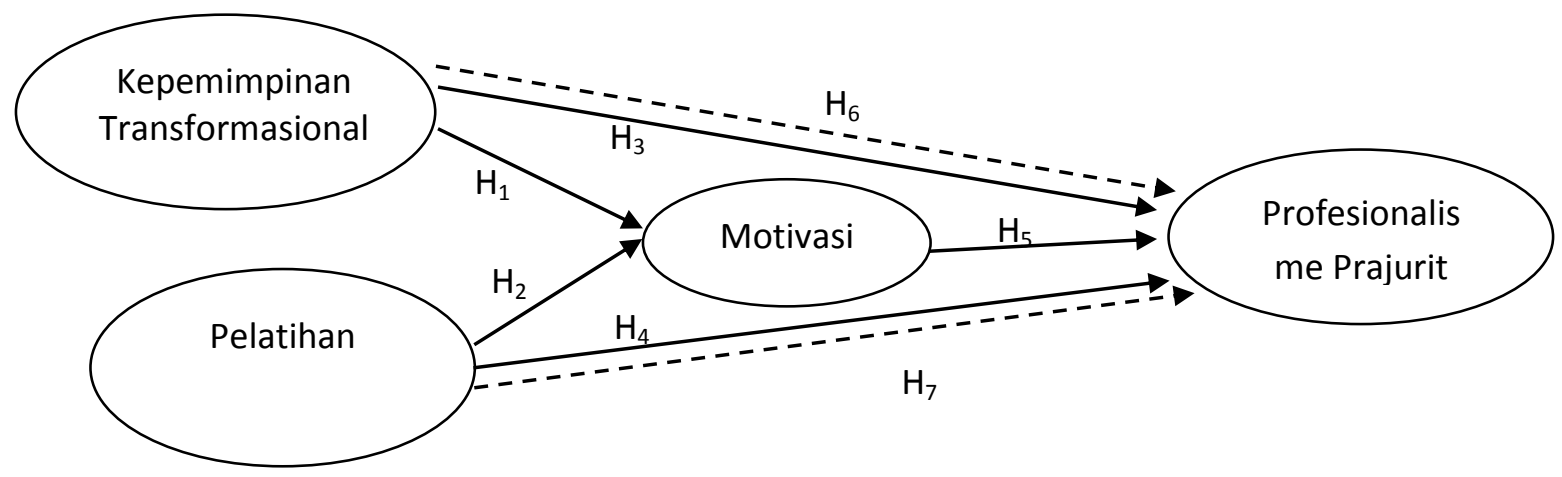

\section{Gambar Kerangka Penelitian}

Hipotesis penelitian diantaranya:

H1 : Kepemimpinan trasformasional berpengaruh terhadap motivasi prajurit di jajaran Satuan Lintas Laut Militer Jakarta.

H2 : Pelatihan berpengaruh terhadap Motivasi di jajaran Satuan Lintas Laut Militer Jakarta.

H3: Kepemimpinan transformasional berpengaruh terhadap profesionalisme prajurit di jajaran Satuan Lintas Laut Militer Jakarta.

H4: Pelatihan berpengaruh terhadap profesionalisme prajurit di jajaran Satuan Lintas Laut Militer Jakarta.

H5: Motivasi berpengaruh terhadap profesionalisme prajurit di jajaran Satuan Lintas Laut Militer Jakarta.

H6: Motivasi memediasi pengaruh Kepemimpinan trasformasional berpengaruh terhadap profesionalisme prajurit di jajaran Satuan Lintas Laut Militer Jakarta.

H7 : Motivasi memediasi Pelatihan berpengaruh terhadap profesionalisme prajurit di jajaran Satuan Lintas Laut Militer Jakarta.

\section{HASIL DAN PEMBAHASAN}

Dengan menggunakan Uji CFA melalui kriteria nilai $G O F$, hasil penelitian ini membuktikan bahwa data telah fit sehingga peneliti dapat menuju test selanjutnya. 


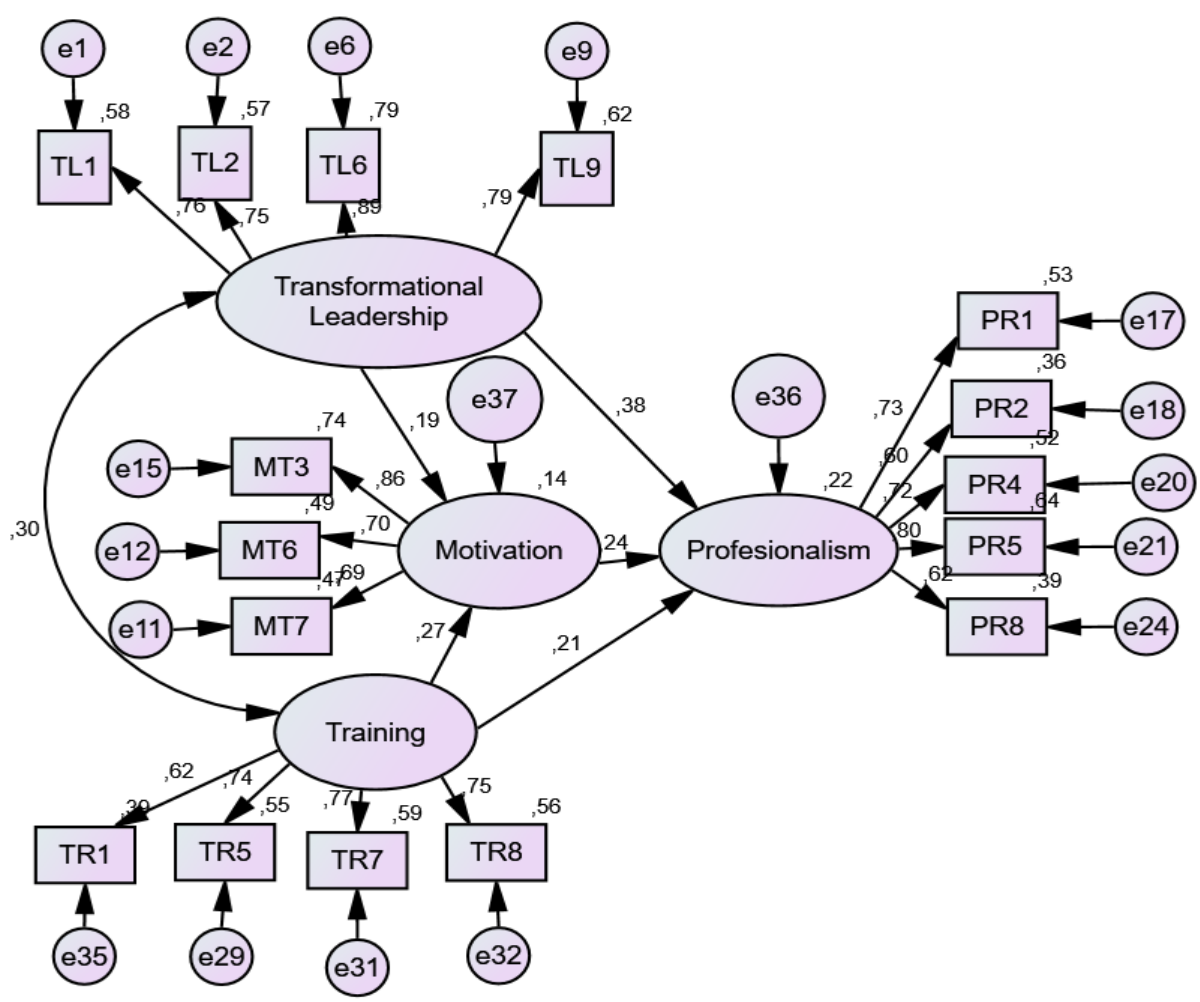

Chi-Square $=97,106 ; \mathrm{df}=98 ; \operatorname{Prob}=, 507 ; \mathrm{cmin} / \mathrm{df}=, 991$

;RMR=,077; $\mathrm{AGFI}=, 921 ; \mathrm{GFI}=, 943 ; \mathrm{CFI}=1,000 ; \mathrm{TLI}=1,001$

Gambar uji $\boldsymbol{C F A}$

Berdasarkan hasil diatat, rangkuman output uji CFA dijabarkan sebagai berikut:

Tabel Rangkuman Uji CFA

\begin{tabular}{|c|c|c|c|c|}
\hline No. & $\begin{array}{l}\text { Goodness of Fit Cut off Value } \\
\text { factor }\end{array}$ & Hasil Analisis & Evaluasi Model \\
\hline 1. & CMIN/DF & $<2$ & 0,991 & Fit \\
\hline 2. & Prob & $\geq 0,05$ & 0,507 & Fit \\
\hline 3. & CFI & $\geq 0,9$ & 1,000 & Fit \\
\hline 4. & TLI & $\geq 0,9$ & 1,001 & Fit \\
\hline 5. & GFI & $\geq 0,9$ & 0,943 & Fit \\
\hline
\end{tabular}

Berdasarkan hasil, terlihat bahwa uji CFA telah sesuai dengan kriteria GOF.Dalam hal ini, model memiliki kecocokan sehingga dapat dilakukan analisis selanjutnya.

Tabel Regression Weight

\begin{tabular}{|c|c|c|c|c|c|c|}
\hline & & & Estimate & S.E. & C.R. & $\mathrm{P}$ \\
\hline Motivation & $<---$ & Training & 257 & ,088 & 2,911 &, 004 \\
\hline Motivation & $<---$ & Transformational_Leadership &, 179 & ,081 & 2,212 &, 027 \\
\hline Profesionalism & $<---$ & Transformational_Leadership & ,340 &, 080 & 4,269 & $* * *$ \\
\hline Profesionalism & $<---$ & Training &, 189 & 082 & 2,296 &, 022 \\
\hline Profesionalism & $<---$ & Motivation & ,226 &, 085 & 2,651 & ,008 \\
\hline
\end{tabular}


Berdasarkan tabel regression weights didapatkan bahwa variabel training mempengaruhi Motivasi dengan nilai estimate 0,257, Prob 0,004 kurang dari 0,05 serta Critical Ratio 2,911>1,96. Kemudian Transformational Leadership (Kepemimpinan Transformasi) mempengaruhi Motivasi secara positif dengan nilai estimate 0,179, Probability 0,027 kurang dari 0,05 serta CR 2,212 >1,96. Lalu Transformational Leadership (Kepemimpinan Transformasi) mempengaruhi Profesionalisme secara signifikan, Prob 0,000 diatas 0,05 dan nilai CR 4,269 > 1,96. Lalu Training positif mempengaruhi Profesionalisme, prob 0,022 kurang dari 0,05 serta CR 2,296 > 1,96. Lalu Motivation berpengaruh positif terhadap Profesionalisme dengan estimate 0,226, Prob 0,008 jauh kurang dari 0,05 dan nilai CR 2,651 >1,96.

Selanjutnya dilakukan uji bootsrap dalam AMOS untuk menguji hipotesis motivasi sebagai mediasi:

Tabel Bootstrap

Standardized Indirect Effects (Group number 1 - Default model)

\begin{tabular}{|l|rrrr|}
\hline & Training & Transformational_Leadership & Motivation & Profesionalism \\
\hline $\begin{array}{l}\text { Motivation } \\
\text { Profesional }\end{array}$ &, 000 &, 000 &, 000 &, 000 \\
ism &, 084 &, 045 &, 000 &, 000 \\
\hline
\end{tabular}

Standardized Indirect Effects - Lower Bounds (BC) (Group number 1 - Default model)

\begin{tabular}{|l|rrrr|}
\hline & Training & Transformational_Leadership & Motivation & Profesionalism \\
\hline Motivation &, 000 &, 000 &, 000 &, 000 \\
Profesionalism &, 027 &, 004 &, 000 &, 000 \\
\hline
\end{tabular}

Standardized Indirect Effects - Upper Bounds (BC) (Group number 1 - Default model)

\begin{tabular}{|l|rrrr|}
\hline & Training & Transformational_Leadership & Motivation & Profesionalism \\
\hline Motivation &, 000 &, 000 &, 000 &, 000 \\
profesionalism &, 184 &, 073 &, 000 &, 000 \\
\hline
\end{tabular}

Standardized Indirect Effects - Two Tailed Significance (BC)

(Group number 1 - Default model)

\begin{tabular}{|l|rrrr|}
\hline & Training & Transformational_leadership & Motivation & Profesionalism \\
\hline Motivation & $\ldots$ & $\ldots$ & $\ldots$ & $\ldots$ \\
Profesionalism &, 002 &, 028 & $\ldots$ & $\ldots$ \\
\hline
\end{tabular}

Hasil analisis dari tabel di atas memperlihatkan bahwa nilai tidak langsung Training terhadap Profesionalism $=0.084$. Bias-corrected confidance interval $95 \%$ memberikan hasil estimasi berkisar antara 0.027 (lower) dan 0.184 (upper), dengan nilai $p=0.002$. Hasil estimasi tidak memberikan angka nol artinya hasil uji signifikan. Motivation memediasi secara tidak langsung pengaruh Training terhadap Profesionalism. Kemudian Standardized indirect effect Transformational_Leadership terhadap Profesionalism $=0.045$. Bias-corrected confidance interval 95\% memberikan hasil estimasi berkisar antara 0.004 (lower) dan 0.073 (upper), dengan nilai $p=0.0028$. Hasil estimasi tidak memberikan angka nol artinya hasil uji signifikan. Motivation memediasi secara tidak langsung pengaruh Transformational_Leadership terhadap Profesionalism.

\section{Pembahasan}


Fakta di lapangan menjelaskan bahwa seorang prajurit yang professional memiliki pemimpin yang transformative. Pemimpin satlinlamil memiliki karisma dan mempengaruhi prajurit untuk senantiasa menjaga profesionalismenya. Organisasi militer merupakan organisasi yang padat manusia, responden menyatakan bahwa mereka selalu mendapatkan dukungan dari pemimpin yang reformis dan peduli. Hasil kuesioner menjelaskan bahwa rata-rata responden memiliki pemimpin yang transformative dalam menjaga integritas dan profesionalisme prajurit. Di sisi lain, prajurit yang tidak professional merasa memiliki pemimpin yang otoriter. Pelanggaran profesi mulai dari kasus desersi, kelalaian, hingga narkotika dan kekerasan terjadi karena pemimpin tidak mampu mendapatkan dukungan dari bawahan. Wawancara singkat dengan NF menyatakan bahwa "prajurit yang melakukan pelanggaran terhadap profesi, umumnya merasa tertekan oleh keadaan dan tindakan pimpinan sehingga melakukan pembangkangan atau pelanggaran”.

Hasil ini sesuai dengan beberapa penelitian terdahulu yang meneliti tentang pengaruh pelatihan dan kepemimpinan terhadap profesionalisme seperti yang dilakukan Neolaka (2015). Robbins and Judge (2015) serta Douglas (2006) menguatkan bahwa kepemimpinan transformasional berpengaruh terhadap profesionalisme. Kepemimpinan transformasional dapat dinilai dari tingkat kepercayaan, keyakinan, sehingga pemimpin dapat mengarahkan dengan jelas tugas secara profesional. Kemudian dikuatkan oleh Nurdin (2013) yang menunjukkan bahwa kepemimpinan transformasional memiliki pengaruh terhadap profesionalisme. Marzuki (2018) juga melakukan penelitian dengan hasil yang sama. Bertentangan dengan Annisa (2018) menganalisis kepemimpinan Hitler saat ingin mentransformasi ras bangsa Jerman kepada pengikutnya, justru menyebabkan demoralisasi yang jauh dari profesionalisme. Berdasarkan teori, hasil penelitian dan fakta di lapangan dapat disintesiskan bahwa kepemimpinan transformasional dalam Satlinlamil mempengaruhi profesionalisme prajurit.

Variabel pelatihan berpengaruh terhadap profesionalisme prajurit. Hasil tersebut sesuai dengan temuan di lapangan bahwa responden melakukan berbagai macam pelatihan dalam rangka membangun profesionalisme. Pelatihan-pelatihan operasi dalam militer baik perang maupun selain perang. Berdasarkan wawancara singkat dengan responden didapatkan fakta di lapangan bahwa responden memerlukan kejelasan dari pelatihan yang diikuti, peserta pelatihan akan lebih tinggi kinerjanya dan mencapai profesional dalam organisasinya ketika mampu mengikuti pelatihan atau diklat dengan sungguh-sungguh. Berdasarkan teori pelatihan \& fakta di lapangan hasil ini sesuai dengan beberapa penelitian terdahulu yang meneliti tentang pengaruh pelatihan terhadap profesionalisme, seperti yang dilakukan oleh Kurniasari (2014) dan Subari (2015) memiliki hasil yang menunjukkan bahwa pelatihan berpengaruh signifikan terhadap profesionalisme kerja, yang berarti bahwa pelatihan kerja akan membentuk kompetensi yang mendukung pegawai dalam mencapai profesionalisme kerjanya.

Variabel motivasi berpengaruh terhadap profesionalisme. Dalam Wawancara singkat, responden dengan inisial AF menyatakan: "Prajurit yang berada di pangkalan memiliki motivasi yang lebih tinggi dibandingkan yang bertugas di kapal perang, hal tersebut juga menunjukkan bahwa prajurit yang melakukan pelanggaran profesionalisme lebih sering terjadi di kapal perang dibandingkan di pangkalan." Hasil ini diperkuat oleh teori Motivasi Maslow (1943). Senada dengan teori Maslow, Kreitner (2011) menjelaskan bahwa motivasi organisasi merupakan cerminan dimana seorang bawahan mengenali organisasi dan terikat kepada tujuan-tujuannya. Motivasi menjadi salah satu faktor yang mempengaruhi profesionalisme. Hasil tersebut dikuatkan oleh penelitian Rahmawati (2016) bahwa motivasi berpengaruh terhadap profesionalisme. Kemudian juga dikuatkan oleh penelitian Muhajirin (2017) dalam hal ini motivasi mempengaruhi profesionalisme prajurit. 
Gaya kepemimpinan berpengaruh terhadap variabel motivasi seperti yang dipaparkan diatas. Hal tersebut berdasarkan pada model hasil perhitungan goodness of fit pada model hipotesis yang dibuat. Responden dalam penelitian menyatakan lebih termotivasi ketika pemimpin mau melibatkan prajurit dalam pengambilan keputusan. Pemimpin satlinlamil memiliki melakukan berbagai cara dalam memotivasi bawahannya. Responden menyatakan bahwa mereka selalu mendapatkan motivasi dan dukungan dari pemimpin. Hasil kuesioner menjelaskan bahwa rata-rata responden memiliki pemimpin yang transformative memiliki motivasi yang tinggi. Wawancara singkat dengan NF menyatakan bahwa "prajurit memiliki pemimpin yang peduli dan memotivasi sehingga senantiasa bertugas dengan baik". Prajurit mendapat dukungan moril maupun materil, mulai dari dukungan keuangan bagi prajurit yang berduka dan kesulitan hingga dukungan dalam karir sehingga prajurit senantiasa termotivasi. Sesuai teori motivasi Maslow (1943), dorongan untuk bekerja secara totalitas sebagai bagian dari pekerjaan dan tanggung jawab dalam mencapai tujuan. Pemimpin yang melibatkan prajurit dalam tim kecil maupun organisasi akan meningkatkan motivasi, dalam hal ini dorongan untuk bekerja secara totalitas (motivasi) timbul dari keterlibatan, rasa saling peduli dan memahami. Anggota pegawai akan merasakan tanggung jawab yang lebih besar sehingga motivasi mereka menjadi lebih tinggi. Penjelasan dan petunjuk dari atasan untuk bawahan dalam bertindak, dapat diharapkan untuk mengurangi ambiguitas dan konflik peran. Hasilnya, motivasi karyawan meningkat. Carvalho (2013) juga menguatkan bahwa semakin tinggi gaya kepemimpinan tranformasional maka semakin tinggi motivasi karyawan. Dalam penelitiannya kepemimpinan transformasional berpengaruh secara signifikan terhadap motivasi Karyawan Perusahaan X di Blitar.

Variabel pelatihan berpengaruh terhadap motivasi. Pada dasarnya pelatihan atau diklat merupakan kebutuhan dasar yang tidak dapat dielakkan. Kegiatan pelatihan dapat meningkatkan kompetensi sehingga prajurit memiliki motivasi dalam menyelesaikan tugasnya dengan baik. Oleh karena itu dibutuhkan pelatihan dalam rangka memotivasi aktualisasi diri yang dibutuhkan prajurit. Responden dalam penelitian juga menjelaskan bahwa pelatihan yang dilakukan dalam Satlinlamil meningkatkan motivasi dalam pekerjaannya. Pelatihan teknis maupun nonteknis merupakan cara pemenuhan kompetensi dan motivasi bagi prajurit dalam menyelesaikan tugasnya. Prajurit senantiasa melakukan pelatihan mulai dari pelatihan menembak, menyelam, jurit tangkas dan halang rintang hingga pelatihan motivasi prajurit. Menurut Komandan Satlinlamil Jakarta Kolonel Laut SS, bahwa setiap prajurit melakukan latihan, tujuannya adalah penguasaan prajurit terhadap kompetensi yang dibutuhkan dengan latihan yang terus-menerus dan berkesinambungan, prajurit termotivasi untuk melakukan tugasnya dengan baik. Surya dan Megawati (2016) melakukan analisis pada peelatihan terhadap motivasi karyawan Swiss-Belinn Hotel Manyar Surabaya, hasilnya terdapat hubungan positif pelatihan terhadap motivasii karyawan. Secara keseluruhan, penilaian responden terhadap variabel pelatihan dan motivasi tergolong tinggi. Pada dasarnya pelatihan atau diklat merupakan kebutuhan dasar yang tidak dapat dielakkan. Kegiatan pelatihan dapat meningkatkan kompetensi sehingga prajurit memiliki motivasi dalam menyelesaikan tugasnya dengan baik. Oleh karena itu dibutuhkan pelatihan dalam rangka memotivasi aktualisasi diri yang dibutuhkan prajurit. Responden dalam penelitian juga menjelaskan bahwa pelatihan yang dilakukan dalam Satlinlamil meningkatkan motivasi dalam pekerjaannya. Pelatihan teknis maupun nonteknis merupakan cara pemenuhan kompetensi dan motivasi bagi prajurit dalam menyelesaikan tugasnya.

\section{KESIMPULAN}

Kesimpulannya Kepemimpinan trasnformasional dan Pelatihan berpengaruh terhadap motivasi kerja. Kepemimpinan trasnformasional, pelatihan dan motivasi berpengaruh terhadap 


\section{○ Jan Lucky Boy Siburian}

profesionalisme. Motivasi memediasi kepemimpinan trasnformasional dan pelatihan terhadap profesionalisme.

\section{REFERENSI}

Ceiik, A., \& Ozsoy, N. (2016). Organizational Change: Where Have We Come From and Where Are We Going? International Journal of Academic Research in Accounting, Finance and Management Sciences, 6(1), 134-141. https://doi.org/10.6007/IJARAFMS/v6-i1/2004

Dessler, G. (2010). Manajemen Sumber Daya Manusia (edisi kesepuluh). Jakarta Barat: PT Indeks.

Eliyanto, E., \& Wibowo, U. B. (2013). Pengaruh jenjang pendidikan, pelatihan, dan pengalaman mengajar terhadap profesionalisme guru sma muhammadiyah di kabupaten kebumen. Jurnal Akuntabilitas Manajemen Pendidikan, 1(1), 34-47.

Hair, J. F., Hult, G. T. M., Ringle, C. M., \& Sarstedt, M. (2014). A primer on partial least squares structural equation modeling (PLS-SEM). Thousand Oaks, CA: Sage Publication.

Hayes, A. F. (2013). Introduction to mediation, moderation, and conditional process analysis: A Regression-Based Approach. New York: The Guilford Press.

Nathan, B, C. (2012). Understanding the Perceptions of Professionalism in Athletic Training with the use of a Professionalism Questionnaire (Doctoral dissertation, Kent State University).

Neolaka, A. (2015). Hubungan Kepemimpinan Transformasional Dan Budaya Organisasi Dengan Profesionalisme Guru (Studi Kasus Di SMA Negeri 47 Jakarta). Jurnal Manajemen Pendidikan, 4(2), 155-170.

Noe, Raymond A. 2003. Human Resource Management, Gaining a Competitive Advantage,. Fourth Edition, McGraw-Hill International Edition.

Oerip, S. P., dan Utomo, T. T. 2012. Mengatasi Krisis Manusia di Perusahaan. Jakarta: PT. Gramedia Widiasarana Indonesia.

Rahmawati, I. F. (2012). Hubungan Antara Motivasi Kerja Dengan Profesionalisme Guru (Doctoral dissertation, Universitas Muhammadiyah Surakarta).

Rahmawati, S. (2015). Pengaruh Pelatihan, Pengalaman Mengajar dan Kompensasi Terhadap Profesionalisme Guru di SMK Negeri 3 Palu. Katalogis, 3(12).

Rakib, M., Rombe, A., \& Yunus, M. (2017). Pengaruh Pelatihan Dan Pengalaman Mengajar Terhadap Profesionalitas Guru (Studi pada Guru IPS Terpadu yang Memiliki Latar Belakang Pendidikan dalam Bidang Pendidikan Ekonomi). Jurnal Ad'ministrare, 3(2), 137-148. 


\section{○ Jan Lucky Boy Siburian}

Riana, I. G. (2016). Pengaruh Kepemimpinan Transformasional terhadap Motivasi dan Kinerja Karyawan (Studi Kasus pada Pt. pandawa). E-Jurnal Ekonomi dan Bisnis Universitas Udayana, 3, 44706.

Riana, I. G. (2017). Pengaruh Kepemimpinan Transformasional Terhadap Kinerja Karyawan Dengan OCB Sebagai Variabel Mediasi. E-Jurnal Ekonomi dan Bisnis Universitas Udayana, 6, 2761-2788.

Robbins, S., \& Judge, T. A. (2013). Organizational Behavior 15th ed. Zhurnal Eksperimental'noi i Teoreticheskoi Fiziki. https://doi.org/10.12737/4477

Robbins, S., \& Coulter (2014). Organizational Behavior 15th ed. Zhurnal Eksperimental'noi i Teoreticheskoi Fiziki. https://doi.org/10.12737/4477

Robbins, S. P., \& Judge, T. A. (2014). Organizational behavior: Student value edition.

Rowland, Andrew W., (2016). "What is Professionalism? The Validation of a Comprehensive Model of Professionalism" Masters Theses \& Specialist Projects.

Rosing, K., \& Zacher, H. (2017). Individual ambidexterity: The duality of exploration and exploitation and its relationship with innovative performance. European Journal of Work and Organizational Psychology, 26(5), 694709. https://doi.org/10.1080/1359432X.2016.1238358

Sari, Putri Desmala (2018) Pengaruh kepemimpinan transformasional kepala sekolah dan motivasi kerja guru terhadap profesionalisme guru. Jurnal Repository Universitas Sanata Dharma. 13(13).

Siagian. (2008). Manajemen Sumber Daya Manusia (Edisi. Pertama). Jakarta: Binapura Aksara.

Simamora, Henry. 2006. Manajemen Sumberdaya Manusia. Yogyakarta: Sekolah. Tinggi Ilmu Ekonomi YKPN. 